\title{
Hubungan Antara Motivasi Berprestasi Terhadap Kinerja Tutor Di PKBM Patriotik
}

\author{
Irfan Bau ${ }^{1}$, Rusdin Djibu ${ }^{2}$ \\ Jurusan Pendidikan Luar Sekolah, Fakultas Ilmu Pendidikan, Universitas Negeri Gorontalo \\ irfanbau@gmail.com, rusdindjibu@ung.ac.id
}

Received: 04 September 2020; Revised: 11 Desember 2021; Accepted: 13 Desember 2021

\begin{abstract}
This Study aims to tesr and empirically prove: is there a relationship between achievement motivation andtutor performance at SPNF Bone Bolango. The population of this study was 30 tutors in PKBM Patriotik, and the total sample of this study was 30 tutors. The sampling techique in this study wassaturatedsamples where the entire population was sampled. The data obtained from the data collection were analyzed using regression analysis. The results of regresion analysis test showed that the significant value of tcount is lower than alpha, and the value of the $t_{\text {count }}$ is higher than the $t_{\text {table. Thus, }} \mathrm{H} 0$ is rejected, and $\mathrm{H} 1$ is accepted, or achievement motivation has a positive and significant relationship to the tutor's performance of achievement motivation (X) is $0.000<0.05$ and $t_{\text {count }} 4.146>t_{\text {table }}$ 1.701. Thus, the $\mathrm{t}$ test hypothesis for Ha (achievement motivation variable) is related therefore, the first hypothesis (Ha) can be proven or accepeted.

Keywords: Achievement motivation, tutors performance.
\end{abstract}

\begin{abstract}
ABSTRAK
Penelitian ini bertujuan untuk menguji dan membuktikan secara empiris: apakah terdapat Hubungan antara motivasi berprestasi dengan kinerja tutor di PKBM Patriotik.Populasi dalam penelitian ini adalah Tutor di PKBM Patriotik berjumlah 30 Responden dan jumlah sampel 30 orang tutor. Teknik penarikan sampel dalam penelitian ini adalah sampel jenuh dimana seluruh populasi dijadikan sampel. Data yang diperoleh dari hasil pengumpulan dan analisis data menggunakan analisis regresi.Berdasarkan tabel uji hipotesis di atas dapat dijelaskan bahwa pada pengujian ini memiliki nilai signifikan $0,000<0,05$ artinya bahwa hubungan kedua variabel signifikan, atau dengan kata variabel motivasi berprestasi mempunyai hubungan yang signifikan terhadap variabel kinerja tutor di PKBM Patriotik. Hasil uji analisis regresi menunjukkan bahwa nilai signifikansi thitung lebih rendah dari alpha, dan nilai thitung lebih besar dari ttabel. Dengan demikian $\mathrm{H} 0$ ditolak dan $\mathrm{H} 1$ diterima atau motivasi berprestasi mempunyai hubungan positif dan signifikan terhadap kinerja tutor motivasi berprestasi (X) adalah $0,000<0,05$ dan thitung 4,146 > ttabel 1,701. Dengan demikian hipotesis uji t untuk Ha (variabel motivasi berprestasi) berhubungan sehingga hipotesis pertama (Ha) dapat dibuktikan atau diterima.
\end{abstract}

Kata kunci: Motivasi berprestasi, kinerja tutor.

(C)2021 by Irfan Bau, Rusdin Djibu Under the license CC BY-SA 4.0

\section{PENDAHULUAN}

Di era globalisasi sekarang ini pendidikan sangatlah penting bagi semua orang. Bekal pendidikan yang dimiliki oleh setiap individu akan bermanfaat dan berkembang baik apabila dapat digunakan dengan melakukan persaingan yang Jambura Journal of Community Empowerment Vol. 2 No. 2, Desember 2021 (Halaman 101-111) 101 
kompetitif. Dengan semakin berkembangnya era sekarang ini membuat kinerja para guru juga harus semakin berkembang. Selain itu, bersamaan dengan itu bangsa Indonesia sedang dihadapkan pada fenomena yang sangat dramatis, yakni rendahnya daya saing sebagai indikator bahwa pendidikan belum mampu menghasilkan sumber daya manusia (SDM) yang berkualitas.

Pendidikan merupakan suatu bentuk investasi jangka panjang yang sangat penting bagi manusia. Pendidikan yang berhasil akan menciptakan manusia yang mampu berkontribusi dengan masyarakat serta tidak menyusahkan masyarakat lain. Masyarakat yang paling terkebelakang sampai yang paling maju akan mengakui bahwa pendidikan dan tutor merupakan satu diantara sekian banyak unsur pembentuk utama calon anggota masyarakat. Pendidikan yang berhasil akan menciptakan manusia yang pantas dan dihormati di masyarakat sehingga menjadi penting pendidikan untuk mencetak manusia yang berkualitas dan berdaya saing. Tutor dapat diibaratkan sebagai pembimbing perjalanan yang berdasarkan pengetahuan, pengalaman serta mampu bertanggung jawab atas kelancaran perjalanan warga belajar dalam mengikuti pembelajaran. Dalam proses pembelajaran warga belajar tentu adanya beberapa hal yang mempengaruhi seperti motivasi, hubungan warga belajar dan tutor, rasa aman dan keterampilan tutor dalam berkomunikasi atau berinteraksi dengan warga belajar yang menjadi faktor pentting bagi tutor dalam proses pembelajaran. Dimana dalam proses belajar pada warga belajar dapat dirumuskan sebagai suatu aktivitas mental atau psikis yang berlangsung dalam interaksi yang aktif.

Tutor dituntut memiliki kinerja yang mampu memberikan dan merealisasikan harapan dan keinginan semua pihak terutama masyarakat umum yang telah mempercayai sekolah dan tutor dalam membina anak didik. Namun tidak semua tutor dapat bekerja sesuai harapan dan tujuan serta memiliki kinerja yang tinggi. Secara umum mutu pendidikan yang baik menjadi tolak ukur bagi keberhasilan kinerja yang ditunjukkan tutor. Motivasi berprestasi tutor yang tinggi dalam bekerja disuatu sekolah akan memberikan dampak positif baik bagi individu maupun organisasi atau sekolah, begitu pula sebaliknya. Adanya 
motivasi berprestasi yang tinggi dapat meningkatkan hasil kerja atau kinerja tutor, manajemen sekolah, dalam konteks ini harus memberikan jalan terbaik, dengan jalan lebih memperhatikan para tutor agar mereka dapat bekerja secara efektif. Motivasi berprestasi yang tinggi akan mempunyai semangat, keinginan dan energi yang besar dalam diri individu untuk bekerja seoptimal mungkin. Motivasi berprestasi yang tinggi pada tutor akan membawa dampak positif bagi proses belajar mengajar di sekolah dan meningkatkan daya saing tutor. Apabila motivasi berprestasi rendah akan menurunkan daya saing antar tutor.

Dalam dunia kerja, motivasi memiliki unsur penting dalam kinerja tutor, sebab motivasi merupakan kemampuan seseorang untuk mencapai suatu tujuan yang diharapkan.

Motivasi berprestasi pada tutor dapat didefinisikan sebagai unsur yang membangkitkan, mengarahkan, dan mendorong seorang tutor untuk melakukan tindakan dan mengatasi segala tantangan dan hambatan dalam upaya untuk mencapai tujuan pendidikan. Motivasi beprestasi ini yang menyebabkan seorang tutor untuk bersemangat dalam menjalankan tugas sebagai pendidik terutama sebagai pengajar karena telah terpenuhi kebutuhannya untuk berprestasi, tutor yang mempunyai motivasi berprestasi akan mempunyai tanggungjawab yang tinggi untuk bekerja dengan antusias dan sebaik mungkin menggerahkan segenap kemampuan dan keterampilan guna mencapai prestasi yang optimal.

Mengacu pada pembahasan tersebut diatas, peneliti berusaha untuk memaparkan beberapa kesenjangan yang nampak berdasarkan pengamatan dalam praktek di lembaga pendidikan non formal, khususnya di PKBM Patriotik. PKBM merupakan suatu lembaga pendidikan yang diselengarakan diluar sistem pendidikan formal.

Kinerja adalah sesuatu yang secara aktual orang kerjakan dan dapat diobservasi, kinerja mencakup tindakan-tindakan dan perilaku yang relevan dengan tujuan organisasi. Kinerja bukan konsekuensi atau hasil tindakan, melainkan tindakan itu sendiri. Sedarmayanti (2017 : 285).

Sesuai data yang diperoleh dari pengelola PKBM Patriotik pada tahun Jambura Journal of Community Empowerment Vol. 2 No. 2, Desember 2021 (Halaman 101-111) 103 
ajaran 2018-2019 pada saat obeservasi bahwa jumlah tutor yang berada di PKBM Patriotik yakni 38 orang tutor yang terdiri dari tutor Pendidikan Kesetaraan (Paket A, Paket B, Paket C), Pendidikan Keaksaraan Fungsional, Life Skill (Kecakapan Hidup), Pendidikan Anak Usia Dini (PAUD), Kelompok Belajar Usaha (KBU). Dengan berbagai data yang di peroleh peneliti dari pengelolah PKBM Patriotik khususnya tutor PKBM Patriotik, peneliti mendapatkan tingkat kinerja tutor di PKBM Patriotik dalam proses pembelajaran masih kurang dengan berbagai hal yang terjadi sepertimasih ada tutor yang terlihat duduk-duduk sambil mengobrol dengan tutor lainnya, ada beberapa tutor yang ijin keluar, ada tutor yang mengobrol di gerbang pintu masuk PKBM, dan masih ada tutor yang datang ke PKBM terlambat. Berbagai permasalahan tutor di atas makin menunjukkan pentingnya upaya meningkatkan kinerja tutor.

Dengan demikian jika hal ini dibiarkan berlartu-larut tanpa adanya penangananya maka akan secara langsung mempengaruhi tingkat pembelajaran yang berada di PKBM Patriotik khususnya warga belajar:

Tabel 1. Pendidikan Terakhir Tutor di PKBM

\begin{tabular}{cc}
\hline Program & Jumlah Tutor \\
\hline Paud & 7 \\
Keaksaraan & 16 \\
Kesetaraan & 7 \\
\hline Total & 30 \\
\hline
\end{tabular}

Berdasarkan data hasil observasi di PKBM Patriotik terdapat tutor yang tingkat kinerjanya masih belum sesuai yang diharapkan seperti kurangnya dukungan teknis dari para penilik PLS, Tenaga Lapangan Dikmas dan Pamong Belajar Sanggar Pendidikan Non Formal dalam pelaksanaan proses pembelajaran yang disebabkan oleh kurangnya informasi kepada penyelenggara kegiatan tentang berbagai kesulitan yang dihadapi oleh Tutor, ada kecenderungan para tutor kurang mampu mengembangkan keahlian sesuai dengan tingkat pendidikan yang dimiliki, ada hasil kecenderungan dengan tidak maksimal kinerja para tutor karena belum memiliki pengalaman kerja yang memadai, tutor mengajar tidak sesuai dengan kita harapkan, maka untuk memotivasi tutor yang rendah diperlukanpemberian motivasi dikalangan tutor, dimana motivasimerupakan daya Jambura Journal of Community Empowerment Vol. 2 No. 2, Desember 2021 (Halaman 101-111) 104 
dorong yang menciptakan kegairahan seseorang baik yang berasal dari dalam maupun dari luar yang mendorong untuk mau bekerja dengan segala upayanya untuk mencapai tujuan tertentu.Hal ini didasarkan pada hasil penelitian Wardana (2013) dikutip dari Jurnal Ilmiah Psikologi Terapan, dari penelitian ini membuktikan bahwa hipotesis penelitian yang menyatakan bahwa ada hubungan antara motivasi berprestasi dengan kinerja dapat diterima. Dengan terbuktinya hipotesa penelitian, maka dapat dipahami bahwa adanya kebutuhan berprestasi yang tinggi dapat meningkatkan kinerja guru yang sudah disertifikasi. Dengan motivasi berprestasi yang tinggi, menyebabkan tutor memiliki keinginan kuat untuk melakukan hal-hal dengan lebih baik dan memiliki tanggung jawab pribadi dalam menemukan jawaban terhadap suatu masalah. Hal ini juga dapat menyebabkan adanya kinerja yang tinggi pada tutor.

Bertitik tolak dari uraian diatas, maka di dalam penelitian ini dapat menemukan secara jelas dan objektif mengenai hubungan antara motivasi berprestasi dengan kinerja tutor, yang diharapkan nantinya akan memberikan kontribusi yang positif bagi PKBM terutama bagi warga belajar.

Kinerja tutor adalah perilaku tutor dalam membelajarkan peserta didik melalui proses belajar mengajar. Hal-hal yang berkaitan dengan pengertian tersebut dalam dunia pendidikan adalah mendidik, mengajar dan melatih. Mendidik berarti meneruskan dan mengembangkan nilai-nilai hidup. Mengajar berarti meneruskan dan mengembangkan ilmu pengetahuan dan teknologi sedangkan melatih berarti mengembangkan keterampilan-keterampilan pada peserta didik. Oleh karenanya pada prinsipnya kinerja tutor adalah kemampuan yang merupakan pencerminan penguasaan tutor akan kompetensinya serta ditunjukkan dalam unjuk kerja yang merupakan pelaksanaan tugas kesehariannya.

Pernyataan diatas didukung salah satu pendapat para ahli Leonard (2008:4) mengemukakan bahwa kinerja tutor adalah hasil kerja yang dicapai oleh tutor sesuai dengan wewenang dan tanggung jawabnya untuk mencapai tujuan organisasi, meliputi adanya sasaran/target, kuantitas, kualitas, efektifitas dan efisiensi dalam pelaksanaan proses pembelajaran. 
Pengertian kinerja guru menurut Burhanudin (2007), mengemukakan bahwa kinerja tutor adalah gambaran kualitas kerja yang dimiliki tutor dan termanifestasi melalui penguasaan dan aplikasi atas kompetensi tutor. Pandangan ini menunjukan bahwa kinerja pada dasarnya merupakan gambaran dari penguasaan dan aplikasi terhadap kompetensi tutor dalam mengaktualisasikan tugas dan perannya sebagai tutor.

Berdasarkan berbagai pengertian di atas, maka dapat disimpulkan bahwa kinerja tutor merupakan hasil pekerjaan atau prestasi kerja yang dilakukan oleh seorang tutor berdasarkan kemampuan mengelola kegiatan belajar mengajar, yang meliputi perencanaan pembelajaran, pelaksanaan pembelajaran, evaluasi pembelajaran dan membina hubungan antar pribadi (interpersonal) dengan warga belajarnya.

\section{METODE}

Adapun yang menjadi tempat penelitian ini di PKBM Patriotik dengan sasaran penelitian adalah Tutor diPKBM Patriotik.

Penelitian ini menggunakan pendekatan kuantitatif untuk mengetahui hubungan yang tedapat pada variabel $(\mathrm{X})$ yaitu kompetensi sosial tutor sebagai variabel bebas dan variabel (Y) yaitu motivasi belajar sebagai variabel terikat dengan penelitian sebagai berikut:

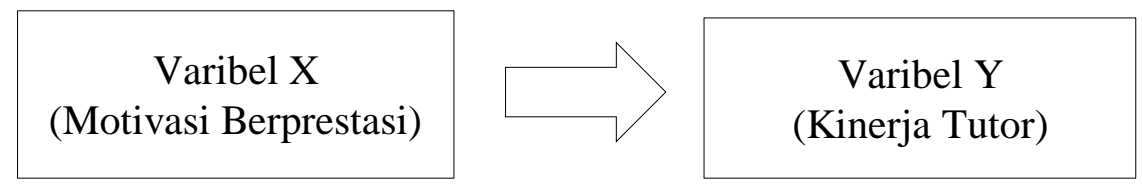

Gambar 2. Hubungan Variabel

Metode penelitian yang digunakan adalah penelitian kuantitatif. Penelitian ini merupakan jenis penelitian asosiatif dengan hubungan kausal dimana terdapat variabel bebas dan terikat. Variabel penelitian ini meliputi variabel dependent dan independent.

1. Variabel dependent biasanya disebut variabel terikat $(\mathrm{Y})$ adalah variabel yang dipengaruhi atau yang menjadi akibat, karena adanya variabel bebas dalam hal 
ini variabel dependent adalah kinerja tutor.

2. Variabel independent bisa disebut dengan variabel bebas (X) adalah variabel yang mempengaruhi atau yang menjadi sebab perubahannya atau timbulnya variabel dependent (terikat). Dalam hal ini variabel dependent/terikat adalah motivasi berprestasi.

\section{HASIL DAN PEMBAHASAN}

\section{Hasil}

Sumber daya manusia menjadi asset terpenting dalam suatu wadah organisasi, baik organisasi vertical maupun horizontal. Sumber daya manusia mempunyai daya fikir, skill, kemampuan yang dapat digalih dan di manfaatkan untuk tujuan bersama. Memiliki sumber daya manusia yang mempunyai kualitas menjadi kekuatan dari sebuah organisasi itu sendiri. Namun untuk memiliki sumber daya manusia yang mempunyai kualitas baik sangat sulit karena tidak semua orang dapat bekerja dengan biak, karena setiap orang memiliki sifat, sikap, serta pola kehidupan yang berbeda.

Kinerja yang baik akan berdampak baik pula pada suatu capaian dan tujuan yang diharapkan sesuai dengan rencana yang telah ditetapkan untuk mendapatkan hasil yang baik setiap pegawai dituntuk untuk bertanggung jawab terhadap masing- masing capaian organisasi yang bersangkutan, secara legal, tidak pernah melanggar hukum serta sesuai moral etika dan tindakan. Dalam hal ini sumber daya manusianya adalah tutor. Dalam mencapai kinerja yang baik seorang tutor harus mendidik, mengajar serta dapat memberikan kualitas dan kuantitas terbaiknya untuk proses pembelajaran. Leonard (2008:4) mengemukakan bahwa kinerja tutor adalah hasil kerja yang dicapai oleh tutor sesuai dengan wewenang dan tanggung jawabnya untuk mencapai tujuan organisasi, meliputi adanya sasaran/target, kuantitas, kualitas, efektifitas dan efisiensi dalam pelaksanaan proses pembelajaran.

Berdasarkan tabel uji hipotesis di atas dapat dijelaskan bahwa pada pengujian ini memiliki nilai signifikan $0,000<0,05$ artinya bahwa hubungan 
kedua variabel signifikan, atau dengan kata variabel motivasi berprestasi mempunyai hubungan yang signifikan terhadap variabel kinerja tutor pada PKBM Patriotik, sebagaimana pada Tabel correlasion berikut ini:

Tabel 1. Correlation (Uji Hipotesis)

\begin{tabular}{llrr}
\hline & & \multicolumn{1}{c}{$\begin{array}{c}\text { Motivasi } \\
\text { berprestasi }\end{array}$} & \multicolumn{2}{c}{$\begin{array}{c}\text { Kinerja } \\
\text { tutor }\end{array}$} \\
\hline $\begin{array}{l}\text { Motivasi } \\
\text { berprestasi }\end{array}$ & Pearson & 1 &, $617^{* *}$ \\
& Correlation & &, 000 \\
& Sig. (2-tailed) & 30 & 30 \\
Kinerja & $\mathrm{N}$ &, $617^{* *}$ & 1 \\
tutor & Pearson & & \\
& Correlation &, 000 & 30 \\
\hline & Sig. (2-tailed) & 30 & \\
\hline
\end{tabular}

\section{Pembahasan}

Baik dan buruknya kinerja pasti dipengaruhi oleh beberapa faktor seperti gaya kepemimpinan, kompensasi yang diberikan, dan salah satunya juga hal terpenting yaitu motivasi, dengan adanya pemberian motivasi dapat mendorong para tutor untuk lebih semangat dalam bekerja, motivasi yang diterima berupa motivasi internal yang berasal dari dalam diri seorang dan motivasi eksternal yang berasal dari luar diri seseorang. Motivasi internal berupa dorongan semangat yang timbul dari kepercayaan dan keberanian seseorang untuk mencapai sesuatu yang diinginkan, sedangkan motivasi eksternal merupakan motivasi dari luar diri seseorang berupa dorongan dan dukungan dari keluarga, sahabat dan orang-orang terdekat terhadap sesuatu yang ingin dicapainya.

Indikator kebutuhan Fisiologis, adalah kebutuhan-kebutuan pokok manusia seperti sandang, pangan, dan perumahan. Kebutuhan ini dipandang sebagai kebutuhan yang paling mendasar bukan saja karena setiap orang membutuhkannya terus menerus sejak lahir hingga ajalnya, akan tetapi juga karena tanpa pemuasan berbagai kebutuhan tersebut seseorang tidak dapat dikatakan hidup secara normal. Dengan adanya indikator tersebut maka diharapkan tutor akan termotivasi untuk bekerja sehingga akan meningkatkan hasil kerja tutor yang baik.

Jambura Journal of Community Empowerment Vol. 2 No. 2, Desember 2021 (Halaman 101-111) 108 
Indikator Kebutuhan Keamanan, kebutuhan akan keamanan yang tidak hanya bersifat fisik akan tetapi juga bersifat psikologis, termasuk perlakuan adil adil dalam pekerjaan seseorang. Keamanan yang diterima pekerja, akan menyebabkan perasaan aman dalam pekerjaan, sehingga pekerja akan melakukan pekerjaan dengan sebaik- baiknya. Dengan begitu tutor akan merasa aman dengan pekerjaannya sehingga akan berdampak pada hasil kerja tutor yang baik.

Pada indikator Kebutuhan Sosial, kebutuhan yang berkisar pada pengakuan akan keberadaan seseorang dan penghargaan atas harkat dan martabatnya. Kebutuhan sosial biasanya tercermin dalam empat bentuk "perasaan" yaitu sense of belonging, sense of importance, need for achievement, dan sense of participation. Pengakuan atas keberadaan dan harkat martabat seseorang, dapat menjadikan seseorang tersebut akan lebih terpacu dalam pekerjaannya karena pengakuan akan diri, harkat, dan martabatnya dari orang lain. Dengan adanya indikator ini maka akan meningkatkan hasil kerja tutor, tutor akan termotivasi untuk bekerja lebih giat untuk mendapatkan hasil yang baik.

Kebutuhan esteem, kebutuhan akan pengakuan atas keberadaan dan statusnya oleh orang lain. Dikaitkan dengan kehidupan organisasional, pada umumnya semakin tinggi kedudukan dan status seseorang dalam suatu organisasi dan di lingkungan masyarakat semakin banyak pula simbol-simbol yang digunakannya untuk menunjukan status yang diharapkannya diterima dan diakui oleh orang-orang lain. Hal tersebut dapat memacu seseorang untuk berjuang demi mendapat pengakuan atas keberadaan dan statusnya oleh orang lain. Pada indikator ini berupa pujian atau pengakuan dari rekan kerja tutor untuk hasil kerja yang diberikan, dengan begitu maka semangat tutor akan bertambah dan dapat memeberikan hasil kerja yang baik.

Kebutuhan Aktualisasi Diri, kebutuhan akan pengembangan berbagai potensi yang dimiliki seseorang. Pengembangan akan potensi-potensi yang dimiliki oleh seseorang dapat mengakibatkan seseorang akan memberikan sumbangan yang lebih besar bagi kemajuan organisasi dan dari kemajuan profesional tersebut, seseorang akan dapat memuaskan jenis kebutuhan lainnya. 
Dengan pengembagan dari potensi tutor dengan begitu prestasi-prestasi dan kemampuan-kemampuan tutor akan memberikan dampak pada hasil kerja nanti.

Berdasarkan hasil penelitian tentang kinerja tutor yang ada di PKBM Patriotik dengan sebaran angket kepada instrument sudah mempunyai jawabannya bahwa kinerja tutor yang ada di PKBM Patriotik baik hal ini karena didukung oleh motivasi berprestasi yang selalu diterima oleh setiap tutor sehingga mereka terdorong dan semangat untuk mendidik, membimbing dan memberikan pembelajaran dengan baik sehingga dampaknya terhadap kinerja juga baik. dari beberapa indikator motivasi bahwa tutor sering mendapatkan motivasi kerja baik itu dari kebutuhan fisikologis, kebutuhan sosial, keamanan, eksteem dan aktualisasi diri dengan begitu tutor akan merasa terdorong untuk bekerja dan loyal terhadap kerja dan kepuasan kerja setiap tutor tercapai.

\section{SIMPULAN}

Berdasarkan hasil penelitian ini maka peneliti dapat menyimpulkan bahwa Motivasi berprestasi mempunyai hubungan terhadap kinerja tutor di memiliki nilai signifikan $0,000<0,05$ artinya bahwa hubungan kedua variabel signifikan, atau dengan kata variabel motivasi berprestasi mempunyai hubungan yang signifikan terhadap variabel kinerja tutor pada PKBM Patriotik. Hasil tersebut dapat dijelaskan sebagai berikut:

1. Indikator yang motivasi kerja yang paling berpengaruh pada kinerja tutor yaitu kebutuhan fisiologis dan kebutuhan keamanan

2. Motivasi dari pimpinan maupun kerabat kerja terlihat terjalin dengan baik, dapat memberikan dampak positif terhadap kinerja tutor

\section{DAFTARPUSTAKA}

A.M, Sardiman. 2014. Interaksi dan Motivasi Belajar Mengajar. Jakarta: Rajawali Pers.

Akdon, Riduwan. (2007). Rumus dan Data dalam Aplikasi Statistika. Bandung: Alfabeta 
Arikunto, S. 2010. Prosedur Penelitian Suatu Pendekatan Praktik. Jakarta: Rineka Cipta

Burhanudin, 2007. Analisis Administrasi Manajemen dan Kepemimpinan Pendidikan. Bumi aksara, Jakarta.

Danim Sudarwan. 2012. Motivasi Kepemimpinan dan Efektivitas Kelompok. Jakarta. PT. Rineka Cipta.

Hamzah B. Uno. 2014. Teori Motivasi Dan Pengukurannya Analisis di Bidang Pendidikan. Jakarta: Bumi Aksara

Leonard, (2008). Pengaruh Motivasi Kerja Dan Suasana Lingkungan Kerja Terhadap Kinerja Guru Matematika Di Sekolah Imanuel Pondok Melati. Jakarta; Jurnal

Mohamad Surya, 2004. Psikologi Pembelajaran dan Pengajaran, Pustaka Bany Quraisy, Bandung

Siagian, Sondang. 2012. Teori Motivasi dan Aplikasinya. Jakarta: Rineka Cipta. Slameto. 2013. Belajar dan Faktor-faktor yang Mempengaruhinya. Jakarta: PT. Rineka Cipta.

Sugiarto. 2005. Pengaruh Persepsi Guru Tentang Kepemimpinan Kepala Sekolah, Kompetensi, dan Motivasi Terhadap Kinerja Guru SMK Seni dan Kerajinan Kota Surakarta

Sugiyono. 2011. Metode Penelitian Kuantitatif, Kualitatif dan R\&D. Bandung: Alfabeta

Suliyah. 2013. Pengaruh Motivasi Berprestasi Dan Sikap Siswa Pada Mata 